\title{
Territory vegetation structure and habitat preferences of the Savi's Warbler Locustella luscinioides in lake Tåkern, Sweden
}

\author{
Vegetationsstrukturer i revir och habitatpreferenser hos vassångare Locustella \\ luscinioides $i$ Tåkern
}

\author{
ADAM BERGNER \& LARS GEZELIUS
}

\begin{abstract}
Savi's Warbler Locustella luscinioides has established as a nesting species in a few shallow reed lakes of southern Sweden during the last twenty years. Knowledge of the habitat requirements of a newly established species is important to maintain a viable population and design action plans. We examined the vegetation parameters in occupied territories of Savi's Warblers at Lake Tåkern, the country's stronghold for the species. We found association with the outer edge zones and fragmented areas of vegetation dominated by common reed Phragmites australis. Occupied territories differed from randomly chosen unoccupied (control) sites by having a thicker layer of basal litter, and on average more willow bushes (Salix spp.). Reed density and height did not differ between oc-
\end{abstract}

cupied territories and control sites. It is likely that the Tåkern population will continue to increase until it is limited by lack of willows or dense basal litter, the traits important for the establishment of territories. It is also likely that the species will continue to increase in Sweden as long as suitable reed habitats are left unaffected.

Adam Bergner, IFM Biology, Division of Ecology, Linköping University, S-58183 Linköping, Sweden. Email: adam.bergner@yahoo.se

Lars Gezelius, Tåkern Field Station, Box 204, S-595 22 Mjölby, Sweden.E-mail: lars.gezelius@lansstyrelsen.se

Received 27 February 2013, Accepted 6 August 2013, Editor: D. Hasselquist

\section{Introduction}

Passerines associated with reed environments need to establish territories that can provide a suitable habitat and sufficient food supply. In reed-nesting passerines, nest predation rate is generally high (Hansson et al. 2000, Batáry et al. 2004). Especially vulnerable are species that breed in less dense stands of reed and reed in shallow water. Since predation is an important factor influencing habitat selection in birds, studies on the utilization of structures found within occupied territories are important for understanding the breeding biology. On the European continent, several studies have analyzed the habitat requirements and the breeding biology of the Savi's Warbler Locustella luscinioides (see Dittberner \& Dittberner 1985, Pikulski 1986, Aebischer et al. 1996, Neto \& Gosler 2005, Neto 2006), but the knowledge is still limited in the northern parts of its European distribution. As a breeder, the species has a short history in Sweden. The first confirmed breeding was in Lake Hammarsjön, Scania, in 1992 (Svensson et al. 1999). Four years later, the first nest was found in Lake
Tåkern (Gezelius 1996), and since the beginning of the 2000s the species has established a small population at this location, apparently breeding annually. During the same period the number of established territories has shown a steady increase (Figure 1), so far peaking at a total of 16 in the spring of 2012 (Gezelius \& Nilsson 2013). Presently, Lake Tåkern is probably one of few locations in southern Sweden that holds a small, but well-established and increasing, population of Savi's Warblers (Bergner 2012). No previous studies on the species have been conducted in Sweden. Hence, the importance of various vegetation parameters connected to habitat selection is poorly understood. In order to understand the species' breeding biology, it is also important to shed light on vegetation structure of occupied territories. The Swedish population is small, probably not exceeding 30 pairs (Ottosson et al. 2012), so the risk of local extinction due to random events is substantial (Tjernberg 2010). Restoration and protection of habitats for birds associated with reed environments is important because such habitats have been affected by human activity through fragmentation (Paracuellos 2006) 
and declined due to drainage of wetlands and eutrophication (Van der Putten 1997). More recently, reed habitats have also been affected as a result of extensive grazing by moulting Greylag Geese Anser anser (Nilsson et al. 2001). The purpose of this study was to examine the habitat preferences for the Savi's Warbler and describe vegetation parameters of occupied territories at an important breeding site in southern Sweden, that is, at the species' northwestern distribution range limit.

More specifically, we examined the following issues in our study: is there any difference in reed height, reed density, basal litter thickness and abundance of bushes and trees between territories occupied by Savi's Warblers and unoccupied sites (potentially suitable as territories)?

\section{Methods}

\section{General biology}

As a reed-specialist, the Savi's Warbler is associated with vegetated lakes, estuaries and bays in large parts of southern and central Europe east to southwestern Siberia (Svensson et al. 1999). The species spends the winter in sub-Saharan Africa

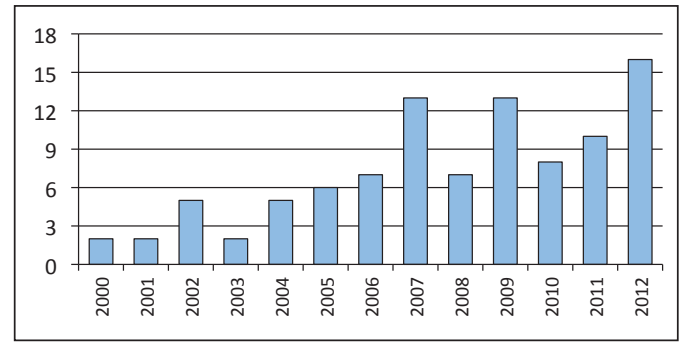

Figure 1. The number of territorial Savi's Warblers in Lake Tåkern during the period 2000-2012, based on data from annual inventories.

Antalet revirhävdande vassångare $i$ Tåkern under perioden 2000-2012, baserat på data från årliga inventeringar).

(Cramp 1992) and arrives to its South and Central European nesting grounds from the beginning of March, and to the Swedish breeding sites during the second half of April. As in most long-distance migrant warblers, the males arrive in general 1-2 weeks before the females (Pikulski 1986). The nest is built in dense basal vegetation and tussocks at low levels in reed and sedge vegetation, occasionally just $10-20 \mathrm{~cm}$ above the water surface (Neto 2006). The males claim and defend their territories with a monotonous, mechanical buzzing song that can be heard in minute-long intervals without

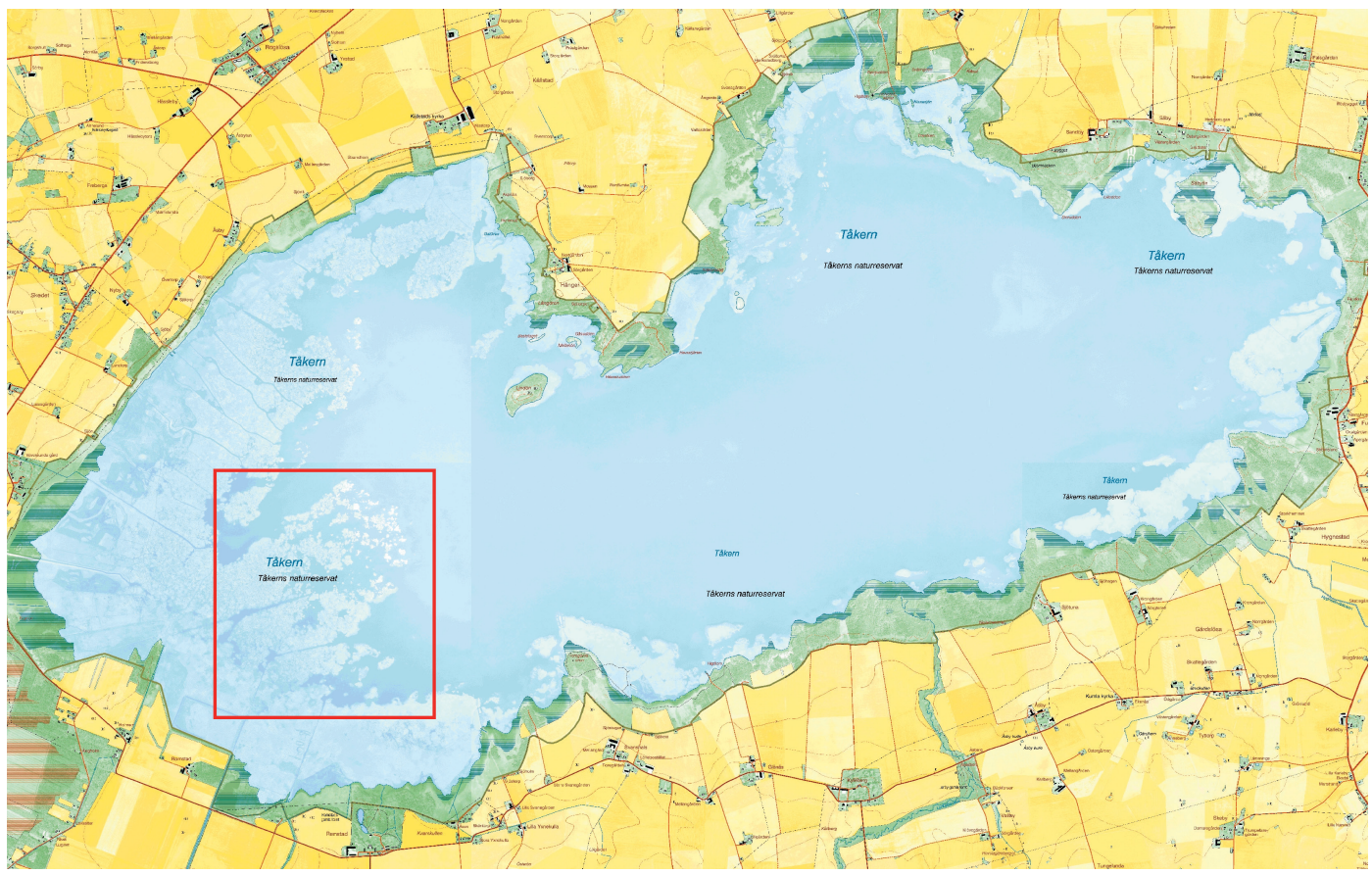

Figure 2. Map of Lake Tåkern with the censusing area.

Karta över sjön Tåkern, Östergötland med experimentområde. 


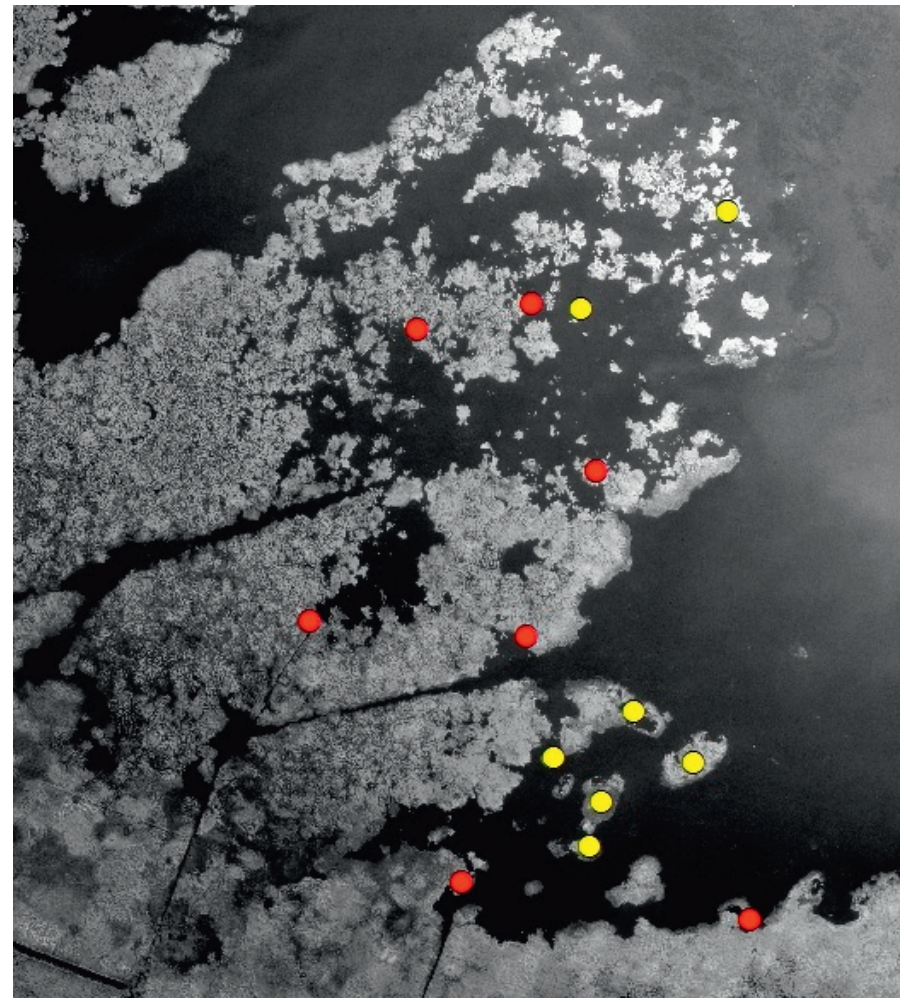

Figure 3. Map of the reed habitats in the censusing area with occupied territories (yellow) and pseudo-territories (red).

Karta över vassområdena inom experimentområdet med besatta revir (gul) och pseudorevir (röd) markerade.

a break. After mating and during the nestling period, the males sing only occasionally (Kloubec \& Čapek 2005), but some individuals can start defending a secondary territory (Neto et al. 2010).

\section{Description of the location}

The survey of Savi's Warblers was conducted in the shallow, mesotrophic $42 \mathrm{~km}^{2}$ Lake Tåkern, in southern Central Sweden $\left(58^{\circ} 21^{\prime} \mathrm{N}, 14^{\circ} 47^{\prime} \mathrm{E}\right)$. The lake is protected as a nature reserve since 1975 and is included within the Ramsar Convention as a wetland of international importance for biodiversity, especially birds. The area specifically studied, the southwestern part of the lake (Figure 2), contains some of the largest reeds of northern Europe making up an area of 1200 ha. The reed beds are crisscrossed by numerous man-made canals, and the reed edges are fragmented, consisting of bays, lagoons and reed isles of various sizes. The emergent vegetation is typical of shallow, nutritious lakes in southern Sweden. Dense belts of common reed Phragmites australis form stands and other species like common cattail Typha latifolia, narrowleaf cattail Typha angustifolia, iris Iris pseudacorus, common tule Schoenoplectus lacustris and sedges Carex spp. are found sparsely (Milberg \& Ekstam, unpublished material).

\section{Data sampling and methodology}

During the period 26 April to 16 May, 2012, the occurrence of Savi's Warblers was assessed mainly by canoeing along the outer reed belts and the canals. Field work was conducted at days with good weather and weak to moderate winds in order to facilitate transportation and the location of territorial males. The survey was limited to the southwestern parts of Lake Tåkern, where the largest number of territories has been found in previous years (Gezelius \& Nilsson 2011). Territorial males react strongly to playback of song in the vicinity of their territories and often come up in full view at the reed edge while they warn or sing against the speaker (personal observations). Early in the season, before the territories are fully established, males may, however, even temporarily leave their areas to approach the speaker. Previously not recommended by Aebischer et al. (1996), we therefore did not use this method in censusing established territories, but just occasionally to study if previously located sites were still occupied. For playback, a standard smartphone and an external very powerful mini speaker (RadioShack ${ }^{\circledR}$ Mini Amplifier) were used. Playback sounds included song interspersed with contact calls. At the first visit to the censusing area, the positions of males relative to each other were located and coordinates registered using a GPS (Garmin GPSMAP® ${ }^{\circledR} 2$ st). Any realignment among singing males was noted during the following week after arrival in order to investigate if the birds were truly territorial. During this period we took notes of the male movements in order to assess the size and vegetation structures of the territories. A total of 12 occupied territories were located, but since this study was conducted 
using a limited time frame we only had time to include seven randomly selected territories for further studies (Figure 3).

One to two weeks after each male's arrival, we measured vegetation parameters at 10 randomly selected points (at least 5 meters apart) in the vicinity of the most frequently used song position in each territory. The purpose of these point measurements was to provide representative data of territory vegetation structures. Parameters measured included: (1) The number of reed stalks within squares of $0.25 \mathrm{~m}^{2}$ at each half meter above the water surface, between $0.5 \mathrm{~m}$ and $3.5 \mathrm{~m}$ reed height. From this, mean reed height was calculated according to Aebischer et al. (1996) using the formula:

$$
A R H=\frac{1}{R D_{0.5}} \sum_{h=0.5}^{3.5}\left(R D_{h}-R D_{h+0.5}\right) h
$$

$A R H=$ average reed height, $h=$ reed height in meters, $R D_{h}=$ reed density (the number of reed stalks within $0.25 \mathrm{~m}^{2}$ ) at reed height $h$.

Only last year's reed stalks were counted as sprouts gradually emerged during the study period, and probably did not affect the species' choice of habitat. (2) The thickness of the basal stratum (Figure 4) assessed at the same ten points by measuring the thickness of vegetation debris from last year that was lying just above the water surface, from the upper surface down to the water surface. (3) The presence of willow shrubs was assessed by counting the number of individual bushes within each territory while standing on a two meter high kitchen-ladder placed at reed edges. Identification of occurring shrubs was not made due to difficulties to safely distinguish the species early in the growth season. The presence of trees such as common alder Alnus glutinosa and birch Betula sp. was noted in a similar manner.

\section{Pseudo-territories}

In order to make comparisons with the vegetation parameters sampled in occupied territories, socalled pseudo-territories were designed (see Aebischer et al. 1996). These were constructed to reflect the average vegetation in areas lacking Savi's Warblers. Because the size of occupied territories in Lake Tåkern has not been previously described, results from other European studies were used for proper evaluation. Aebischer et al. (1996) found

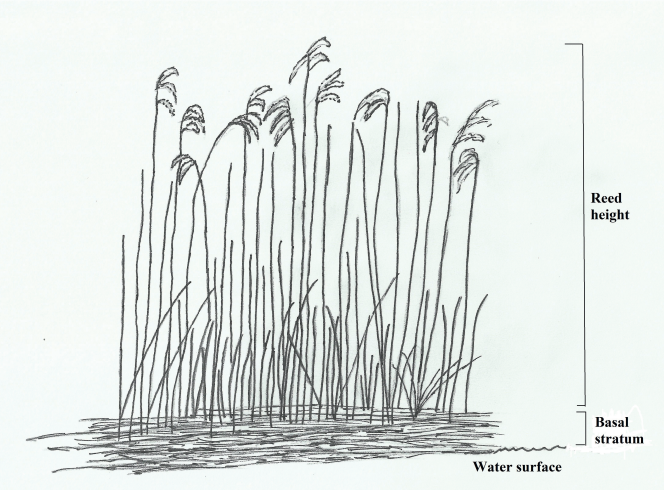

Figure 4. Descriptive illustration of the reed and some parameters mentioned in the text.

Illustration av vass med förklaringar till parametrar omnämnda i uppsatsen.

that the territory size varied between 500 and 3300 $\mathrm{m}^{2}$. In a study conducted in Hungary, Báldi (2004) found that the smallest territories in fragmented reed beds (similar to those found in Lake Tåkern) covered an area of only $380 \mathrm{~m}^{2}$. Based on these data, the size of pseudo-territories in Lake Tåkern was assessed as the average size $\left(1459.24 \mathrm{~m}^{2}\right)$. Measurements of vegetation parameters within pseudo-territories did not start until all measurements in occupied territories were completed. This was mainly done in order to select for similar areas where pseudo-territories could be randomly chosen. All males found during the study period resided in edge zones, thus limiting the potential areas for pseudo-territories to edge areas. Seven pseudo-territories were created using a quadratic grid $\left(\sqrt{1459.24 \mathrm{~m}^{2}}=\operatorname{sides} 38.2 \mathrm{~m}\right)$ on a map of the reed distribution. The pseudo-territories were then chosen by random selection of numbered quadrats using the map of the reed distribution. Once in place in the pseudo-territories, the same vegetation parameters as in occupied territories were measured.

\section{Statistics}

Data on average reed height in occupied territories were tested against corresponding data from pseudo-territories using t-test (significance level of $\mathrm{P}<0.05$ ). The difference in reed density at different reed heights was tested in one-way ANOVAs (significance level of $\mathrm{P}<0.05$ ). Data on basal litter thickness and number of willow bushes did not meet the need for normal distribution, as showed in 


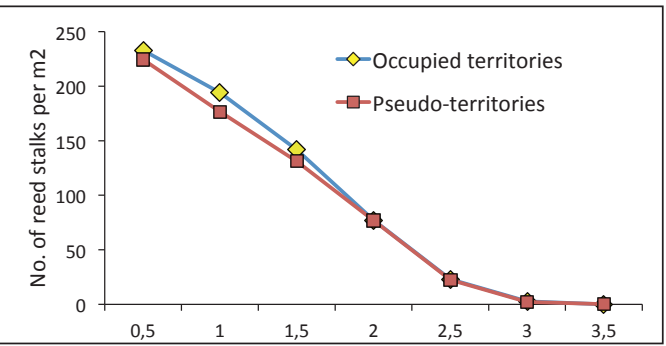

Figur 5. Average number of reed stalks per $\mathrm{m}^{2}$ at different reed heights in occupied territories and pseudo-territories. Genomsnittligt antal vasstrån per $m^{2}$ vid olika vasshöjder för besatta revir och pseudorevir.

\section{Results}

The vegetation over large areas in the surveyed parts of the lake was found to be relatively uniform with a tendency for more variation in terms of density, height and species composition at reed edges. However, usually no other species than common reed formed stocks. Other species occurring more sparsely included narrowleaf cattail, iris, valerian Valeriana officinalis and tufted loosestrife Lysimachia thyrsiflora. Willows were found in six out of seven surveyed territories, showing large variation in the number of shrubs. Of the seven investigated pseudo-territories, willow shrubs were found in two. The number of willows was significantly greater in occupied territories than in pseudo-territories ( $\mathrm{W}=69.5, \mathrm{P}<0.014, \mathrm{~N}=7$ ). Mean number of willows was $11.14 \pm 0.88 \mathrm{SE}$ in occupied territories and $0.71 \pm 0.48 \mathrm{SE}$ in pseudo-territories. Presence of common alder and birch were rare, making no statistical analyses possible.

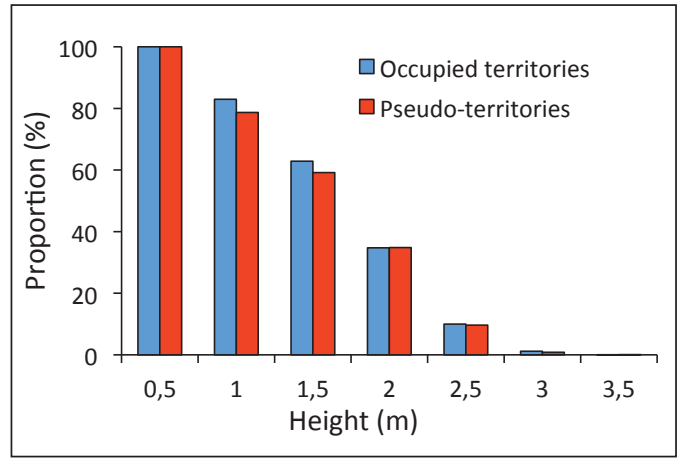

Figur 6. Proportion of reed stalks at different reed heights in occupied territories and pseudo-territories. The number of reed stalks at the lowest level measured, $0.5 \mathrm{~m}$, represents $100 \%$.

Proportionell fördelning $i$ höjd av vasstrån hos besatta revir och pseudorevir. Antalet vasstrån vid den lägsta nivån, $0.5 \mathrm{~m}$, utgör $100 \%$.
Reed heights above 3.5 meters occurred rarely in both the occupied territories and pseudo-territories. The normal maximum height of the reed was within the range from 2.5 to 3.0 meters. The mean reed height was on average $3.6 \%$ higher in occupied territories (mean: $1.47 \pm 6.52 \mathrm{SE} \mathrm{m}$ ) than in pseudo-territories (mean: $1.41 \pm 4.56 \mathrm{SE} \mathrm{m}$ ), but the difference was not significant $(\mathrm{t}=1.17, \mathrm{P}=0.24$, $\mathrm{N}=70$ ). At lower levels, usually $<1.0 \mathrm{~m}$, the proportion of short broken stalks was great. Occupied territories had on average $3.6 \%$ more reed stalks with height $\geq 0.5 \mathrm{~m}(\mathrm{t}=0.55, \mathrm{P}=0.580, \mathrm{~N}=70)$ and $9 \%$ more reed stalks with height $\geq 1.0 \mathrm{~m}(\mathrm{t}=1.38$, $\mathrm{P}=0.170, \mathrm{~N}=70$ ), but the differences were not statistically significant.

The reed structure exhibited typical properties, increasing in density vertically towards the ground. The density (number of reed stalks/area) in occupied territories differed significantly at all measured levels lower than $2 \mathrm{~m}\left(\mathrm{~F}_{6,483}=232.78, \mathrm{P}<0.001\right)$. A similar result was demonstrated for pseudo-territories as well. At heights $>2 \mathrm{~m}$ any changes in the number of individual reed stalks were too small (Figure 5), making statistical tests impossible. The maximum number of reed stalks at the level $0.5 \mathrm{~m}$ differed greatly between individual sample points, ranging from $76-448$ stalks $/ \mathrm{m}^{2}$ in occupied territories and $72-464$ stalks $/ \mathrm{m}^{2}$ in pseudo-territories. When comparing at the level of individual sampling points, the increase in reed height was found to be negatively associated with a decrease in reed density (Pearson $\mathrm{r}=-0.258 ; \mathrm{P}=0.031, \mathrm{~N}=70$ ). Using the formula described above, no significant difference was found in average reed height between occupied and pseudo-territories. At all levels except the highest $(3.5 \mathrm{~m})$, the average reed density was higher in occupied territories than in pseudoterritories (Figure 6). The difference was greatest in the height range from 0.5 to $1.5 \mathrm{~m}$, but at no level the difference was significant $(0.5 \mathrm{~m}: \mathrm{t}=0.55$, $\mathrm{P}=0.580, \mathrm{~N}=70 ; 1.0 \mathrm{~m}: \mathrm{t}=1.38, \mathrm{P}=0.170, \mathrm{~N}=70 ; 1.5$ $\mathrm{m}: \mathrm{t}=1.05, \mathrm{P}=0.296, \mathrm{~N}=70 ; 2.0 \mathrm{~m}: \mathrm{t}=0.03, \mathrm{P}=0.972$, $\mathrm{N}=70$.

The thickness of the basal stratum differed in appearance from a thin layer of broken last year's reed stalks and leaves to very dense mats of laying dry reed. Especially the latter structure was frequently present on at least a few places in most of the occupied territories surveyed. The litter thickness was on average $83.6 \%$ higher in occupied territories (occupied territories: mean $=9.39 \pm 0.93 \mathrm{SE}$ $\mathrm{cm}$, pseudo-territories: mean $=1.54 \pm 0.47 \mathrm{SE} \mathrm{cm}$; $\mathrm{W}=6086.5, \mathrm{P}<0.001)$. 


\section{Discussion}

In Lake Tåkern, homogeneous edge areas predominated by common reed hold most of the Savi's Warbler territories. This is, however, the predominant vegetation type and the only plant species to create substantial stocks in the shallow waters along the shores of the lake. Studies conducted elsewhere in Europe suggest that the species is not primarily linked to common reed only, but also prefers other grassy vegetation with scattered shrubs. In a Spanish study, Martinez-Vilalta et al. (2002) found that the Savi's Warbler avoided homogenous reed and instead preferred vegetation mainly consisting of saw-sedge Cladium mariscus. In Portugal, most nests were found in dense vegetation: rushes Juncus spp., most often mixed with reed, and some in raspberry plants Rubus spp. (Neto 2006). In Lake Neuchâtel, Switzerland, most territorial males were found in vegetation consisting of saw-sedge, cattail or sedges, though in all cases with an element of common reed (Aebischer et al. 1996). These findings of a non-selective preference for different plant species suggest that the Savi's Warbler is not dependent on specific plants, but rather other properties of the vegetation, such as its height and density.

The results of our study suggest that the species prefers some scattered bushes in its territories. Presence of elevated structures, like trees, has been shown to increase nest parasitism in songbirds inhabiting reed (Honza et al. 1998), but Savi's Warblers are very rarely parasitized by Cuckoos. In the few cases where nests have been found depredated in Lake Tåkern, Water Rail Rallus aquaticus predation has most likely been the main cause of brood loss (J. Stepniewski, personal comm.). No previous study has found scattered bushes as being important structures in occupied territories of the Savi's Warbler. Báldi \& Kisbenedek (1999) stated that the species did not show a preference for edges where bushes were plentiful, most likely because of the apparent transition between two different vegetation types. In Lake Tåkern, bushes were found to be rather low and most of the larger structures were found in interior reedbeds, possibly limiting the negative effects of such structures. The importance of willow shrubs for the quality of a territory has not yet been analyzed, and needs further study. In a few cases, Savi's Warblers were observed singing from the top of willow shrubs, most likely as a way to be heard over a wider area and increase the chance of mating.

Neither reed height nor reed density differed sig- nificantly between occupied territories and pseudoterritories in Lake Tåkern. Aebischer et al. (1996) demonstrated both denser and higher reed vegetation in occupied territories in Lake Neuchâtel. Also Neto (2006) showed that most birds were found in vegetation that on average was higher, but this did not seem to be of large importance for nest site selection. In order to find distinct differences in vegetation data, a large number of replicates is usually needed. If any differences truly exist in Lake Tåkern, the reed edges examined in this study were too uniform to reveal such differences. Occupied territories were found to have a slightly higher number of short $(\leq 1.5 \mathrm{~m})$ reed stalks, resulting in denser basal structures in the reed beds. This finding cannot be explained using the data obtained from this study, but indicate that differences in vegetation density might exist. The most important vegetation parameter for the species seems to be an extensive basal stratum of straw litter (broken reed stalks from the previous year). This was confirmed by the study in Lake Tåkern and has previously been discussed by Aebischer et al. (1996) and Neto (2006). A thick layer of straw litter is likely to be important for foraging, which often take place close to the water surface (Winkler \& Leisler 1985). It is also believed that an extensive litter layer is crucial for proper nest positioning.

Typical territories of Savi's Warblers in Lake Tåkern are characterized by being situated at reed edges or in fragmented areas consisting of several reed isles, observations consistent with a previous study conducted in Lake Velence, Hungary (Báldi 2004). These areas are typically influenced by edge effects, which are the combined biotic and abiotic factors affecting the presence and distribution of various organisms along edges (Murcia 1995). In general, many reed living passerines show preferences for edge zones (Báldi \& Kisbenedek 1999). This is believed to be a result of the properties of reed edges, typically exhibiting higher and denser vegetation (Báldi 1999). Reed edges have a drier microclimate than interior reed beds, potentially offering more food for insectivorous birds. Although there are some contradictory results (e.g. Lahti 2001), many studies suggest that edges have higher rates of nest predation (Báldi \& Batáry 2005). Fragmented reed beds might as well exhibit high nest predation due to prominent edge effects. In a study on Reed Buntings Emberiza schoeniclus, a weak positive association between degree of fragmentation and nest predation rates was found (Pasinelli \& Schiegg 2006). Nest site selection is believed to favor those individuals that reduce the 
risk of nest predation (Martin 1998). Having demands for habitats with high predation pressures, the Savi's Warbler needs to find a way to compensate for the increased risk of depredated nests. A thick basal stratum of reed litter is believed important as a substrate for nests. Unlike most warblers of the genus Acrocephalus, the Savi's Warbler builds its nest well hidden at low levels in dense vegetation, possibly as a way of limiting the risk of nest predation (Neto 2006). Equivalently, this can be seen in the Bearded Reedling Panurus biarmicus, a species dependent upon reedbeds having a dense cover of thin, dry reed stems to conceal its nests (Poulin et al. 2002; personal observations). The extensive and dense structures of basal reed litter are more prominent in reed edges and partly a result of mechanical abrasion from winds and ice.

At a local scale, habitat selection is a function of a species' habitat preference, population density and landscape heterogeneity (Fretwell \& Lucas 1970). Because of its early state of establishment in Lake Tåkern, the density of Savi's Warblers is considered low compared to areas within the species' general range. This implies that the distribution of males is not yet limited by lack of suitable territories. Most territories might therefore still be situated in areas of significantly high quality, suggesting that the results from our study reflect only the vegetation parameters of the best territories among those available in this region. The Savi's Warbler territories in Lake Tåkern exhibited an unequal spatial distribution during the spring of 2012, in accordance with previous years (Tåkern Field Station, unpublished material). Despite large areas of suitable reed edges, males tend to be aggregated in clusters within areas of just a few hundred meters of reed. This pattern can easily be interpreted as areas having different quality are unequally distributed in Lake Tåkern. This might not, however, be the only explanation; conspecific attraction is known to play an important role for habitat selection and territory establishment in many songbirds (Ward \& Schlossberg 2004, Hahn \& Silverman 2006, Nocera \& Betts 2010). Vocal attraction to areas including territories of conspecifics might have important implications for breeding success. Laiolo \& Tella (2008) showed, in their study on Dupont's Larks Chersophilus duponti, that the intensity of vocal activity was associated with the likelihood of receiving immigrants to an area, securing population persistence.

Considering the recent increase of territories in Lake Tåkern, as well as confirmed breedings in Lake Kvismaren in 2009 (Stervander et al. 2010) and Lake Krankesjön in 2010 (the Species Gateway; http://svalan.artdata.slu.se/birds), we believe that the species will continue to increase in suitable reed habitats of southern Sweden. Because presence of thick basal strata of broken reed stalks has been shown important, this trait might, over time, be a limiting factor in Lake Tåkern. In order to provide the Savi's Warblers with this vegetation parameter, continuous recruitment of reed is required. How the increased population of Greylag Geese, which feeds particularly on reed sprouts during the moulting period, affects reed passerines in Lake Tåkern has not yet been evaluated. Recruitment of willows is believed to be favored by disturbance, creating spots of bare soil in reed edges. Mechanical abrasion, mostly from ice in early spring, is probably the most important factor influencing the occurrence of such traits. Before we can assess the number of potential territories that areas of the reed habitats of Lake Tåkern can hold, further mapping of reed areas and studies on the correlation between vegetation structures and territory quality is needed.

\section{Acknowledgements}

We wish to express our gratitude to Paul-August Schult for assistance in the field. Professor Per Milberg, IFM Biology, Division of Ecology, Linköping University, supervised during the project. The County Administrative Board (Länsstyrelsen Östergötland) approved the waiver, making the study possible to conduct in the nature reserve. The study was financially supported by the Tåkern Foundation. This is contribution no. 93 from Tåkern Field Station.

\section{References}

Aebischer, A., Perrin, N., Krieg, M., Studer, J. \& Meyer, D.R. 1996. The role of territory choice, mate choice and arrival date on breeding success in the Savi's Warbler Locustella luscinioides. Journal of Avian Biology 27: 143-152.

Báldi, A. 1999. Microclimate and vegetation edge effects in a reedbed in Hungary. Biodiversity and Conservation 8: 1697-1706.

Báldi, A. 2004. Area requirements of passerine birds in the reed archipelago of Lake Velence, Hungary. Acta Zoologica Academiae Scientiarum Hungaricae 50: 1-8.

Báldi, A. \& Kisbenedek, T. 1999. Species-specific distribution of reed-nesting passerine birds across reed-bed edges: effects of spatial scale and edge type. Acta Zoologica Academiae Scientiarum Hungaricae 45: 97-114.

Báldi, A. \& Batáry, P. 2005. Nest predation in European reedbeds: different losses in edges but similar losses in 
interiors. Foolia Zoologica-Praha 54: 285-292.

Batáry, P., Winkler, H. \& Báldi, A. 2004. Experiments with artificial nests on predation in reed habitats. Journal of Ornithology 145: 59-63.

Bergner, A. 2012. Vassångaren (Locustella luscinioides) - en nykomling i Tåkerns fauna (In Swedish). Vingspegeln 31: 69-75.

Cramp, S. (ed.). 1992. The Birds of the Western Palearctic, Vol. 6. Oxford University Press, Oxford.

Dittberner, H. \& Dittberner, W. 1985. Zur Lage und Verteilung der Nistplitze des Rohrschwirls Locustella luscinioides bei der Erst- und Zweitbrut (In German). Vogelwelt 106: 107-111.

Fretwell, S.D. \& Lucas, H.L. 1970. On territorial behaviour and other factors influencing habitat distribution in birds. Acta Biotheoretica 19: 16-36.

Gezelius, L. 1996. Första häckningen av vassångare (Locustella luscinioides) i Östergötland (In Swedish). Vingspegeln 15: 88-89.

Gezelius, L. \& Nilsson, L. (ed.). 2011. Arsrapport 2010 från Tåkerns Fältstation (In Swedish with English abstract): 24.

Gezelius, L. \& Nilsson, L. (ed.). 2013. Arsrapport 2012 från Tåkerns Fältstation (In Swedish with English abstract): in press.

Hahn, B.A. \& Silverman, E.D. 2006. Social cues facilitate habitat selection: American redstarts establish breeding territories in response to song. Biology Letters 2: 337-340

Hansson, B., Bensch, S. \& Hasselquist, D. 2000. Patterns of nest predation contribute to polygyny in the Great Reed Warbler. Ecology 81: 319-328.

Honza, M., Øien, I.J., Moksnes, A. \& Røskaft, E. 1998. Survival of Reed Warbler Acrocephalus scirpaceus clutches in relation to nest position. Bird Study 45: 104-108.

Kloubec, B. \& Čapek, M. 2005. Seasonal and diel budgets of song: a study of Savi's warbler (Locustella luscinioides). Journal of Ornithology 146: 206-214.

Lahti, D.C. 2001. The "edge effect on nest predation" hypothesis after twenty years. Biological Conservation 99: 365-374.

Laiolo, P. \& Tella, J.L. 2008. Social determinants of songbird vocal activity and implications for the persistence of small populations. Animal Conservation 11: 433-441

Martin, T.E. 1998. Are microhabitat preferences of coexisting species under selection and adaptive? Ecology 79: $656-670$.

Martinez-Vilalta, J., Bertolero, A., Bigas, D., Paquet, J.Y. \& Martinez-Vilalta, A. 2002. Habitat selection of passerine birds nesting in the Ebro Delta reedbeds (NE Spain): Management implications. Wetlands 22: 318-325.

Milberg, P. \& Ekstam, B. In prep. Tåkerns växtvärld (In Swedish). Unpublished material.

Neto, J.M. \& Gosler, A.G. 2005. Breeding biology of the Savi's Warbler Locustella luscinioides in Portugal. Ardea 93: 89-100.

Neto, J.M. 2006. Nest site selection and predation in Savi's Warblers Locustella luscinioides. Bird study 53: 171-176.

Neto, J.M., Hansson, B. \& Hasselquist, D. 2010. Low frequency of extra-pair paternity in Savi's Warblers Locustella luscinioides. Behaviour 147: 1413-1429.

Nilsson, L., Kahlert, J. \& Persson, H. 2001. Moult and moult migration of Greylag Geese Anser anser from a population in Scania, south Sweden. Bird Study 48: 129-138.

Nocera, J.J. \& Betts, M.G. 2010. The role of social informa- tion in avian habitat selection. The Condor 112: 222-224

Ottosson, U., Ottvall, R., Elmberg, J., Green, M., Gustafsson, R., Haas, F., Holmqvist, N., Lindström, A.., Nilsson, L., Svensson, M., Svensson, S. \& Tjernberg, M. 2012. Fåglarna $i$ Sverige - antal och förekomst (In Swedish with English summary). SOF, Halmstad.

Paracuellos, M. 2006. Relationships of songbird occupation with habitat configuration and bird abundance in patchy reed beds. Ardea 94: 87-98.

Pasinelli, G. \& Schiegg, K. 2006. Fragmentation within and between wetland reserves: the importance of spatial scales for nest predation in reed buntings. Ecography 29: 721-732.

Pikulski, A. 1986. Breeding biology and ecology of Savi's Warbler at Milicz fishponds. Ptaki Staska 4: 2-39.

Poulin, B., Lefebvre, G. \& Mauchamp, A. 2002. Habitat requirements of passerines and reedbed management in southern France. Biological Conservation 107: 315-325.

Stervander, M., Nielsen, B. \& Rees, J. 2010. Kvismare fågelstation 2009. In Wirdheim, A. \& Bentz, P-G. (ed.) Fågelåret 2009 (In Swedish), Sveriges Ornitologiska Förening.

Svensson, S., Svensson, M. \& Tjernberg, M. 1999. Svensk fågelatlas (In Swedish with English summary). Vår fågelvärld, supplement 31, Stockholm.

Tjernberg, M. 2010. Locustella luscinioides, vassångare. Artfaktablad från Artdatabanken, SLU http://www.artfakta.se/Artfaktablad/Locustella_Luscinioides_103076.pdf

Van der Putten, W.H. 1997. Die-back of Phragmites australis in European wetlands: an overview of the European Research Programme on Reed Die-back and progression (1993-1994). Aquatic Botany 59: 263-275.

Ward, M.P. \& Schlossberg, S. 2004. Conspecific attraction and the conservation of territorial songbirds. Conservation Biology 18: 519-525

Winkler, H. \& Leisler, B. 1985. Morphological aspects of habitat selection in birds. In Cody, M.L. (ed.) Habitat Selection in Birds. Academic Press, London.

\section{Sammanfattning}

Vassångaren Locustella luscinioides är ett nytt tillskott till den svenska fågelfaunan, som under de senaste årtiondena invandrat från sitt huvudsakliga utbredningsområde i södra och mellersta Europa. Efter en första konstaterad häckning i Hammarsjön, Skåne, 1992, har arten etablerat en liten häckande population i sjön Tåkern, Östergötland. Antalet revir har ökat stadigt de senaste åren och som mest hittades där 16 sjungande hanar under vårsäsongen 2012. På grund av begränsad utbredning och liten populationsstorlek riskerar arten att försvinna från södra Sverige till följd av slumpfaktorer. För att kunna förutsäga eventuella hot och utvärdera framtida populationsutveckling i Sverige är studier av artens habitatkrav och häckningsbiologi nödvändiga. Några större studier av arten i Sverige finns dock sedan tidigare inte publicerade. I syfte att ta reda på artens habitatkrav på en viktig svensk häck- 
ningslokal utfördes under våren 2012 vegetationsmätningar i sju etablerade revir i sydvästra delen av Tåkern. Fyra parametrar undersöktes specifikt: vasshöjd, vasstäthet, tjockleken på förnaskiktet och förekomsten av videbuskage och träd. Vegetationsparametrarna jämfördes med sju slumpvist utformade pseudorevir inom samma område, dock med skillnaden att dessa saknade vassångare. Etablerade revir hittades uteslutande i kantzoner och fragmenterade områden dominerade av bladvass Phragmites australis med visst inslag av smalkaveldun Typha angustifolia, läkevänderot Valeriana officinalis och svärdslilja Iris pseudacorus. Inga signifikanta skillnader i vasshöjd eller vasstäthet påvisades, även om etablerade revir i genomsnitt hade något högre vassmedelhöjd. Karaktäristiskt för de flesta etablerade revir var signifikant tjockare basala strukturer av liggande fjolårsvass, i genomsnitt hela $83.6 \%$ tjockare än motsvarande strukturer i pseudorevir. Sannolikt är tjocka basalskikt av förna viktiga som substrat för bon, vilka ofta förläggs i täta tuvor eller fjolårsvegetation på låg nivå i vassen. Eftersom arten huvudsakligen söker föda nära vassbottnen kan dessa strukturer också vara viktiga för födosök. Signifikant fler videbuskage Salix spp. hittades i etablerade revir jämfört med pseudorevir. Förekomst av buskage för betydel- sen av revirkvalitet har ännu inte utvärderats, men vid några tillfällen noterades hur hanar sjöng från toppen av buskage, sannolikt som ett sätt att höras över ett större område och öka chansen att attrahera honor. I denna studie fann vi vassångaren knuten till kantzoner, områden som generellt påverkas av tydliga kanteffekter och som också kan ha högre bopredationsrisk. I likhet med studier av Aebischer m.fl. (1996) och Neto (2006) drar vi slutsatsen att arten väljer områden med vegetationsstrukturer som minskar risken för bopredation, och därmed kompenserar för den ökade risken för bopredation i kantzoner. Med tanke på artens sentida ökning i Tåkern, liksom konstaterade häckningar i Kvismaren, Närke 2009 och Krankesjön, Skåne 2010, talar det mesta för att arten kommer att fortsätta att öka så länge inga plötsliga förändringar sker i artens habitat. Hur den ökade grågåsstammen, som under ruggningsperioden lokalt betar på årsskott av vass och därmed hämmar tillväxten, påverkar vassångaren och andra vasslevande tättingar har ännu inte studerats i Tåkern. Innan vi kan förutsäga hur många revir av vassångare som potentiellt skulle kunna rymmas i Tåkerns vassar krävs vidare kartläggning av vegetationsstrukturer och häckningsbiologiska studier med inriktning på revirkvalitet. 